\title{
Ostrich (Strutio camelus) Meat Protein Quality and Digestibility
}

\section{Author(s)}

Reis LS ${ }^{1}$

Oliveira $\mathrm{TC}^{2}$
Nutritionist, graduated at Centro Universitário do Leste de Minas Gerais - Unileste - MG Brazil.
2 Nutritionist, M.Sc. in Nutrition at Universidade Federal de Viçosa, Brazil; Expert in Management: Foods and Collective Food Service at Universidade Federal de Ouro Preto, Nutritionist graduated at Universidade Federal de Ouro Preto.

\section{ABSTRACT}

The purpose of the study was to evaluate ostrich meat protein quality, as its consumption has significantly increased in the last few years in Brazil. Male Wistar rats were distributed in groupe of six elements. The standard group received a casein-based diet, the control group received a protein-free diet, and the experimental group received ostrich meat diet as protein source. The evaluated biological parameters were protein efficiency ratio (PER), net protein ratio (NPR), net protein utilization (NPU), and true digestibility (TD). There were differences $(p<0.05)$ among treatment groups for all evaluated biological parameters. Mean true digestibility values were $92.12 \%$ and $75.77 \%$ for casein and ostrich meat, respectively.

\section{INTRODUCTION}

Ostrich production has increased in Brazil, and has attracted the interest of farmers, particularly to its potential of producing red meat with low fat content (Marinho et al., 2004; Godoy, 2005).

Ostrich is highly productive, offering quality products with high added value, such as meat, feathers, leather and other byproducts (Souza, 2004; Balog \& Almeida Paz, 2007). Meat is currently the main drive of commercial ostrich production. Despite being consumed and appreciated for a long time, ostrich meat is being rediscovered due to its resemblance to beef in terms of appearance, flavor, and texture (Souza, 2004; Pereira et al., 2006).

The interest in non-conventional animal species, such as ratites (emus and ostriches), for the meat of supply is increasing; nevertheless, the use of these food sources is still poorly documented (Féron, 1995; Pereira et al., 2006).

In Brazil and in other countries of Latin America, Africa and Asia, the wild fauna is an important protein source of food for people, particularly in poor areas (Reis et al., 2007). In large urban centers, the meat of these animals is sold in restaurant and special meat shops with very high prices.

As the ostrich is an exotic bird and its production is relatively recent in Brazil, there are few studies on its nutritional value and possible dietary applications for the prevention and/or treatment of specific pathologies. Therefore, this study aimed at evaluating the protein quality and the digestibility of ostrich meat.

\section{MATERIAL AND METHODS}

In order to prepare the experimental diets, the percentage composition of ostrich meat was determined (Table 1). Analyses were carried out in triplicate using thigh fillet, following the criteria mentioned below. 


\begin{tabular}{lcc}
\hline \multicolumn{3}{l}{ Table $\mathbf{1}$ - Percentage composition of ostrich (Struttio camelus) } \\
meat. & \\
Parameter & $\mathbf{g} / \mathbf{1 0 0} \mathbf{g}$ & $\%$ \\
Protein & 23.9 & - \\
Ashes & 0.87 & - \\
Lipids & 1.13 & - \\
Humidity & - & $81.27 \%$ \\
\hline
\end{tabular}

In order to determine humidity, $5 \mathrm{~g}$ of raw meat were weighed and heated in a circulating-air oven (Nevoni ${ }^{\circledR}$ ) at $105^{\circ} \mathrm{C}$ for 24 hours, according to the methodology described in the Manual of Analytic Norms of the Institute Adolf Lutz (Pregnolato \& Pregnolato, 1985). Total protein was determined using the micro-Kjeldhal method for nitrogen quantification, according to the Association of Official Analytical Chemists (AOAC) (1998). Ashes were determined using $5 \mathrm{~g}$ of the dry sample obtained for humidity analysis: the sample was burnt in a muffle at $525^{\circ} \mathrm{C}$ for 6 hours according to the methodology described in the Manual of Analytic Norms of the Institute Adolf Lutz (Pregnolato \& Pregnolato, 1985). Lipids were determined using the method of Bligh \& Dyer (1959).

The experimental diets (Table 2) were based in AIN93G (Reeves et al., 1993) with protein content fit in 9.5\% (Pires et al., 2006). The test diet was prepared cooking the ostrich meat similarly as to domestic thermal treatment in the Laboratory of Diet Techniques of the Nutrition School of Centro Universitário do Leste de Minas as follows: dry heat was applied for 13 minutes, when the meat reached $98^{\circ} \mathrm{C}$ at the end of the cooking process. The sample was then dehydrated in a forced-ventilation oven (Nevoni ${ }^{\circledR}$ ) at an average temperature of $65 \pm 2^{\circ} \mathrm{C}$ for 8 hours. The cooked and dehydrated meat was ground in a domestic processor (Walita ${ }^{\circledR}$ ) to obtain the meal to be used to manufacture the diet. The meal was placed in duly identified plastic bags and refrigerated $\left(4^{\circ} \mathrm{C}\right)$.

\begin{tabular}{lrrr}
\hline $\begin{array}{l}\text { Table } \mathbf{2}-\text { Composition of the experimental diets } \\
\text { biological assay (g/100g complete diet). }\end{array}$ & \multicolumn{1}{l}{ in the } \\
Ingredients & D1 & D2 & \multicolumn{1}{c}{ D3 } \\
Intrich meat & --- & --- & 13.16 \\
Casein & --- & 13.45 & --- \\
Mineral mix (AIN-93G-MX) & 3.5 & 3.5 & 3.5 \\
Vitamin mix (AIN-93G-VX) & 1 & 1 & 1 \\
Soybean oil & 7 & 7 & 6.85 \\
Choline bitartrate & 0.25 & 0.25 & 0.25 \\
Corn starch (q.S.p 100) & 59.75 & 46.3 & 46.74 \\
L-cystine & 0.3 & 0.3 & 0.3 \\
Food fiber (cellulose) & 5 & 5 & 5 \\
Dextrinized corn starch & 13.2 & 13.2 & 13.2 \\
Sucrose & 10 & 10 & 10 \\
\hline
\end{tabular}

D1- non-protein diet; D2- standard diet (casein); D3- test diet (ostrich meat).
The standard group received the casein-based diet, the control group was fed the nitrogen-free diet, whereas the experimental group received the diet with ostrich meat as protein source.

\section{Animals and biological assay}

Eighteen newly-weaned Wistar var. albinus male rats (Rattus novergicus), with an average age of 21 days, were used. Animals were divided into three groups $(n=6)$, with differences in average group weight not higher than $10 \mathrm{~g}$, as recommended by the AOAC (1997). The rats were housed in individual cages, and maintained at $22 \pm 3^{\circ} \mathrm{C}$ and a 12-h light/dark cycle. Food and water were supplied ad libitum.

During the experimental period, protein efficiency ratio (PER), net protein ratio (NPR), net protein utilization (NPU), and true digestibility (TD) were determined.

PER was calculated according to the AOAC (1975). This method relates weight gain to protein intake. NPR was determined according to Bender \& Doell (1957): the weight gain of the test group is summed to the weight loss of the protein-free group, and the result is divided by the protein intake of the test group. NPU values were established by the nitrogen retention difference between the test group and the control group divided by the amount of nitrogen ingested by the test group. For NPU determination, rats were euthanized on the $14^{\text {th }}$ experimental day, and their carcasses were dried in a forced-ventilated oven at $105^{\circ} \mathrm{C}$ for $24 \mathrm{~h}$. Carcasses were then chilled, weighed, ground, and defatted with petroleum ether in a Soxhlet extractor for $6 \mathrm{~h}$, after which they were macerated to determine the level of nitrogen in the carcass.

In order to calculate digestibility, diets were marked with carmine $(100 \mathrm{mg} / 100 \mathrm{~g}$ diet $)$, and feces were collected between day 7 and 14, and individually stored under refrigeration. After the collection period, feces were dried in a forced-ventilation oven at $105^{\circ} \mathrm{C}$ for $24 \mathrm{~h}$, and then chilled, weighed, defatted, and macerated to determine nitrogen content.

Digestibility indicates protein bioavailability, showing the amount of ingested protein that is hydrolyzed by digestive enzymes ad absorbed by the body. When some peptide bonds are not hydrolyzed during the digested process, part of the protein is excreted in the feces or metabolized by microorganisms in the large intestine (Monteiro et al., 2004). True digestibility was calculated by measuring the amount of nitrogen ingested in the diet, the amount excreted in the feces, and metabolic loss in the feces, which corresponds the fecal nitrogen of the protein-free diet group. 


\section{Data analysis}

Data were submitted to the t-test or analysis of variance (ANOVA), using the test of Duncan to compare treatment means at a $5 \%$ significance level.

\section{RESULTS AND DISCUSSION}

Animal weight gain reflects the quality of the ingested protein source. Therefore, analyzing the variation in body weight between experimental groups (Table 3), we see that the D2 presented the highest weight gain, which was expected, as casein is a protein source with optimal digestibility. This was followed by D3 and D1, respectively. However, no differences ( $p>0.05$ ) were detected between D2 and D3 groups.

\begin{tabular}{|c|c|c|c|c|}
\hline \multirow[t]{2}{*}{ Group } & \multicolumn{2}{|c|}{ Weight (g) } & \multicolumn{2}{|c|}{ Intake (g) } \\
\hline & Final 1 & Weighted variatior & Feed & Protein \\
\hline D11 & $34.16 \pm 2.54$ & $-9.33 \pm 2.62$ & $60.31 \pm 6.45$ & $5.72 \pm 0.36$ \\
\hline $\mathrm{D} 2^{2}$ & $97.00 \pm 10.08$ & $60.00 \pm 9.34$ & $165.96 \pm 19.35$ & $15.76 \pm 1.83$ \\
\hline D3 3 & $107.16 \pm 7.00$ & $57.00 \pm 12.08$ & $170.72 \pm 11.74$ & $16.21 \pm 1.11$ \\
\hline
\end{tabular}

D1- non-protein diet; D2- standard diet; D3- test diet - (see details in Table 2).

Differences $(p<0.05)$ between groups D2 and D3 were observed for all analyzed biological parameters (Table 4). It must be noted that the coefficient of variation was lower than $5 \%$.

\footnotetext{
Table 4 - Mean values of the protein quality biological parameters analyzed in the standard and experimental groups.

\begin{tabular}{|c|c|c|c|c|c|c|}
\hline Group & PER $^{1}$ & $\operatorname{RPER}(\%)^{1 a}$ & $N^{\prime} R^{2}$ & RNPR(\% $)^{2 a}$ & $\mathrm{NPU}^{3}$ & $T D(\%)^{4}$ \\
\hline D2 & 4.38 & 100 & 4.38 & 100 & 60.97 & 92.12 \\
\hline D3 & 4.07 & 92.92 & 2.94 & 67.12 & 61.35 & 75.77 \\
\hline
\end{tabular}

1: PER (protein efficiency ratio); $1^{\text {a }}$ RPER (protein efficiency ratio relative to casein); 2: NPR (net protein ratio); $2^{\text {a }}$ RNPR (net protein ratio relative to casein); 3: NPU (net protein utilization); 4: TD (true digestibility).
}

Babji et al. (1980) experimentally assessed the protein quality of mechanically separated meat of the neck and the back of roasted chicken (NBRC) and of the carcass of cooked chicken (CCC). The relative protein efficiency ratio (RPER) of NBRC and CCC were $93.48 \%$ and $96.58 \%$, respectively, which were slightly higher than that found for ostrich meat in the present study. Although ostrich meat PER value was lower than that determined for casein, it is still higher than the PER value of 2.3 (RPER of 92\%) described by Schaafsma (2000) for beef, as well as that determined by Macneil et al., (1978) for chicken meat, which RPER was $76 \%$ in relation to casein.
PER relates weight gain to the amount of protein ingested during the experimental period; however, any variation in weight gain caused by other effects may generate some confusion as to the protein efficiency of the used diets. Therefore, the parameter NPR and in vivo digestibility are more reliable than PER to determine the protein quality of foods (Sarwar et al., 1989).

As to relative net protein ratio (RNPR), Jong \& Noll (1988) found $92.63 \%$ for frog meat in relation to casein, a slightly higher value than that observed for ostrich meat in the present study, whereas Pires et al. (2006) reported $101.07 \%$ for beef.

Mean in vivo digestibility values were $92.12 \%$ and $75.77 \%$ for casein and ostrich meat, respectively, and presented statistical difference $(p<0.05)$. According to Paleari et al. (1998), the digestibility of lean beef is $92 \%$, whereas other studies showed digestibility values of 88-89\% (Hernandez et al., 1996), 90.3\% (AbdelAzis et al., 1997), and 98\% (Schaafsma et al., 2000).

\section{CONCLUSIONS}

Based on the results obtained under the conditions of the present study, it is possible to conclude that the biological indicators of protein quality of ostrich meat were lower as compared to those of casein.

The information produced by the present study are both nutritionally and economically important, and may contribute for the dissemination of information on ostrich meat in Brazil.

\section{REFERENCES}

Association of Official Analytical Chemists. Official methods of analysis 18th ed.Washington; 1998.

AOAC - Association of Official Analytical Chemists. Official methods of analysis of AOAC International. 16th ed. Maryland; 1997. AOAC - Association of Official Analytical Chemists. Official methods of analysis of the Association of Official Analitycal Chemists. 12 th ed. Washington: AOAC; 1975. 1094p.

Abdel-Azis S, Hussein L, Esmail S, El-Awadi N. In vivo rat assay for true protein digestibility and protein quality of beef and meat products extended with soy protein. Journal Food Science Nutrition 1997; 48(3):51-56.

Babji AS, Froning GW, Satterlee LD. Protein nutritional quality of mechanically deboned poultry meat as predicted by the C-PER assay. Journal Food Science Nutrition 1980; 45:441-443.

Balog A, Almeida Paz ICL. Ostrich (Struthio camellus) carcass yield 
and meat quality parameters. Revista Brasileira de Ciência Avícola 2007; 9(4):215-220.

Bender $A E$, Doell $B H$. Note on the determination of net protein utilization by carcass analysis. British Journal of Nutrition 1957; 11: 138-143.

Bligh EG, Dyer WJ. A rapid method of total lipid extraction and purification. Canadian Journal of Biochemistry and Physiology 1959; 37:911-917.

Féron EM. New food sources conservation of biodiversity and sustainable delepment: can unconventional animal species contribute to feeding the world? Biodiversity and Conservation 1995; 4:233-240.

Godoy LC, Cardozo RM, Moraes GV. Avaliação de diversidade genética em subespécies e cruzamento de avestruzes (Struthio camelus) com o uso de marcadores RAPD. Acta Scienteae 2005; 27(2):199-206.

Hernandez M, Montalvo I, Souza V, Sotelo A. The protein efficiency ratios of 30:70 mixtures of animal vegetable protein are similar or higher than those of animal foods alone. Journal of Nutrition 1996; 126 (1):574-581.

Jong EV, Noll IB. Determinação do valor nutritivo da carne de rã: valor biológico da proteína. Anais do $6^{\circ}$ Encontro Nacional de Ranicultura; 1988; Rio de Janeiro, Rio de Janeiro. Brasil. p. 293298.

Macneil JH, Mast MG, Leach RM. Protein efficiency ratio and levels of selected nutrients in mechanichally deboned poultry meat. Journal Food Science Nutrition 1978; 43:864-865.

Marinho M, Meireles MV, Souza AVG. Determinação da microflora do trato gastrintestinal de avestruzes (Struthio camelus) criados na região noroeste do estado de São Paulo, submetidos à necropsia. Arquivos do Instituto Biológico 2004; 71(3):267-271.

Monteiro MR, Costa NMB, Oliveira MGA, Pires CV, Moreira MA. Qualidade protéica de linhagens de soja com ausência do Inibidor de Tripsina Kunitz e das isoenzimas Lipoxigenases. Revista de Nutrição 2004; 17(2):195-205.

Paleari MA, Camisasca S, Beretta G, Renan P, Corisco P, Bertolo G, Crivelli $G$. Ostrich meat physico chemical characteristics and comparison with turkey and bovine meat. Meat Science 1998; 48:205-210.

Pereira AV, Romanelli PF, Scriboni AB. Rendimentos do abate e composição da carne de ema (Rhea americana). Ciência e Tecnologia dos Alimentos 2006; 26: 632-638.

Pires CV, Oliveira MGA, Rosa JC, Costa NMB. Qualidade nutricional e escore químico de aminoácidos de diferentes fontes protéicas. Ciência e Tecnologia dos Alimentos 2006; 26(1):179-187.

Pregnolato W, Pregnolato NP. Normas analíticas do Instituto Adolf Lutz. São Paulo (SP): Instituto Adolf Lutz; 1985.

Reeves PG, Nielsen FH, Fahey Jr GC. AIN-93 purified diets for laboratory rodents: final report of the American Institute of Nutrition Ad Hoc Writing Committee on the reformulation of the AIN-76 rodent diet. Journal of Nutrition 1993; 123(2):1939-1951.

Reis LS, Oliveira TC, Vilela AF. Análise físico-química da carne de avestruz (Struthio camelus). Anais do $2^{\circ}$ Congresso Mineiro de Alimentação e Nutrição [CD-ROM]; 2007; Ouro Preto, Minas Gerais. Brasil.

Sarwar G, Peace RW, Botting HG, Brule D. Digestibility of protein and amino acids in selected foods as determined by a rat balance method. Plant Foods for Human Nutrition 1989; 1(1):23-32.

Schaafsma G. The protein digestibility-corrected amino acid score. Journal of Nutrition 2000; 130(7):1865-1867. 